\title{
Commentary
}

\section{COVID-19 and healthcare-associated infections}

\author{
Andrea Cioffi* and Raffaella Rinaldi \\ Department of Anatomical, Histological, Forensic and Orthopaedic Sciences, Sapienza University of \\ Rome, Rome, Italy
}

Received 30 July 2020

Accepted 6 August 2020

\begin{abstract}
National Health Systems are facing a very serious health emergency related to COVID-19. In this phase of emergency, it is essential to ensure the care of all affected patients but also to ensure the economic stability of the National Health System. This stability is undermined by the potential exponential increase in claims caused by healthcare-associated infections related to COVID-19. That is why it will be essential to use all means necessary to prevent this economic crisis, which could overlap with the health crisis.
\end{abstract}

Keywords: COVID-19, Sars-Cov-2, healthcare-associated infections, resident doctors

The COVID-19 pandemic is putting a strain on all health workers and on the organization of the National Health Systems itself. Currently, in countering the health effects of the pandemic, one problem could be underestimated, but it could be of considerable importance in the medico-legal and public health field: Healthcare-associated infections related to Sars-Cov-2.

The number of doctors who are COVID-19 positive is increasing exponentially worldwide [1,2], which means that infected healthcare professionals have continued to work and assist patients until testing positive for specific tests. Thus, it happens that health professionals contract the virus during work and transmit it in turn to other patients in hospital facilities.

The situation could potentially precipitate, encouraging confusion and attacks on doctors; in fact, the first alarm bells have already been raised. Recently in Italy, the Health Director of the Hospital of Padua said that young doctors (i.e. doctors in training) could cause an increase in infections within the Hospital. This statement was motivated by the fact that young doctors have a more active social life and are therefore at a high risk of contracting SARS-Cov-2 [3]. These claims led to very strong reactions; for example, the Italian Medical Union (ANAAO) defended young doctors by stating that they are the backbone of the

\footnotetext{
*Address for correspondence: Andrea Cioffi, Department of Anatomical, Histological, Forensic and Orthopaedic Sciences, Sapienza University of Rome, Viale Regina Elena 336, 00161, Rome, Italy. E-mail: an.cioffi19@gmail.com; ORCID: https://orcid.org/0000-0001-5163-9558.
} 
National Health System and cannot be considered as "infectors" [4]. In addition, many resident doctors of Padua have called a strike to protest against the claims of the Health Director [5]. This is only one of the possible consequences of the spread of COVID-19 in hospitals, with the risk that they will seek "scapegoats" to justify deficits of the National Health System. It would be serious to blame young doctors for the spread of COVID-19 in the hospital setting, also because resident doctors are already burdened with considerable responsibility and work stress without protection [6].

This scenario is particularly worrying, especially given that these kinds of healthcare-associated infections could further increase the stress of National Health Systems and, in addition, could result in an exponential increase in claims by patients, with severe expenditure of resources [7].

In the event that the healthcare-associated infection is foreseeable and avoidable, compensation will be granted by the judge. In the case of COVID-19, nosocomial infections contracted due to contact with infected doctors or nurses would surely be grounds for compensation. In fact, these infections would be predictable and avoidable through the strict observance of the technical guidance of the World Health Organization [8].

It is essential to try to prevent healthcare-associated infections caused by Sars-Cov-2 to avoid further increasing the number of COVID-19 patients and to avoid an economic crisis of the National Health Systems related to the huge number of claims for COVID-19 nosocomial infection.

To achieve this objective, it will be necessary for health structures to ensure the safety at work of all health professionals and to require compliance with all specific directives [8].

\section{Conflict of interest}

None to report.

\section{References}

[1] BuzzFeed News. Thousands of US health care workers have been infected by the coronavirus. This is how each state stacks up. Available from: https://www.buzzfeednews.com/article/zahrahirji/us-health-care-workers-coronavirus.

[2] OMCEO Roma. Covid-19. Magi: "Aumentano i medici positivi. Necessario fare i tamponi, non c'è più tempo". Available from: https://www1.ordinemediciroma.it/comunicati-stampa/25434-covid-19-magi-\%E2\%80\%9Caumentano-i-medici-po sitivi-necessario-fare-i-tamponi,-non-c\%E2\%80\%99\%C3\%A8-pi\%C3\%B9-tempo\%E2\%80\%9D.html.

[3] Il Fatto quotidiano. Coronavirus, a Padova il direttore sanitario contro specializzandi: "La loro vita sociale crea pericoli di contagio nei reparti". Poi le scuse. Available from: https://www.ilfattoquotidiano.it/2020/05/02/coronavirus-a-padova-ildirettore-sanitario-contro-specializzandi-la-loro-vita-sociale-crea-pericoli-di-contagio-nei-reparti-poi-le-scuse/5789090/.

[4] ANAAO Assomed. Covid-19: gli specializzandi non sono untori! Anaao Giovani e Als spediscono le accuse al mittente. Le citazioni sulla stampa del comunicato Anaao Giovani. Available from: http://www.anaao.it/content.php?cont=28395.

[5] Il Fatto quotidiano. Padova, "noi specializzandi costretti a lavare le divise a casa e poi accusati di essere pericolo di contagio da covid". Dopo lo sciopero l'azienda annuncia che darà i dati degli infettati sul lavoro. Available from: https://www.ilfattoquotidiano.it/2020/05/06/padova-noi-specializzandi-costretti-a-lavare-le-divise-a-casa-e-poi-accusatidi-essere-pericolo-di-contagio-da-covid-dopo-lo-sciopero-lazienda-annuncia-che-dara-i-dati-degli-infettati-sul-lavo/ 5792632/.

[6] Cioffi A. Professional autonomy of the resident doctor: Between the hammer and the anvil. J Forensic Leg Med. 2020;72:101965. doi:10.1016/j.jflm.2020.101965.

[7] Cioffi A, Rinaldi R. Covid-19 and medical liability: A delicate balance. Med Leg J. 2020 Jul 3;25817220935879. doi:10.1177/0025817220935879.

[8] World Health Organization. Country \& Technical Guidance - Coronavirus disease (COVID-19). Available from: https:// www.who.int/emergencies/diseases/novel-coronavirus-2019/technical-guidance. 